\title{
Marriage and Dependence in Iowa and U.S. Law: Acuff v. Schmit, 1956
}

\author{
KATE HOEY AND JOY SMITH
}

ON THE AFTERNOON of July 15, 1953, Glen Acuff, a 32-yearold construction worker, was permanently incapacitated when his Ford sedan was sideswiped by another car at the intersection of two gravel roads south of Waterloo, Iowa. The driver of the other car, Raymond Schmit, a bank teller from Gilbertville, Iowa, sustained a bump over his right eye. Glen's neck was broken, which resulted in complete paralysis of his lower torso and legs, partial paralysis of his arms and hands, loss of bowel and bladder function, and loss of sexual function. ${ }^{1} \mathrm{He}$ could no longer support his family. His wife, Maude, 31, was a full-time housewife and mother, caring for their four children, ages 4, 5, 7, and 12. Without Glen's income, the Acuffs initially got by with help from Glen's father, state welfare payments, and the Salvation

The authors gratefully acknowledge the encouragement and guidance of University of Iowa professors Linda K. Kerber and Ann Estin. Research that Kate Hoey performed for Professor Peggie Smith, currently at Washington University in St. Louis, on the claim of loss of consortium led the authors to some of the sources and insights here. The authors thank all three professors.

1. There are some contradictions in accounts of the accident. Fred Acuff, Glen's youngest son, recalls that his father remembered that as he was making a left turn, Schmit attempted to pass him on the right and lost control of his vehicle, sideswiping Glen's vehicle and pushing it into a telephone pole. Maude Acuff and Fred Acuff, interview by authors, Boone, Iowa, 3/28/2009. Attorney Frederick White's brief describes the two vehicles traveling in different directions and colliding at the intersection. Appellant's Petition at Law, Acuff v. Schmit, 248 Iowa 272 (Iowa 1956) (No. 10-48939), 3-6. 
Army, where they were active members. Glen and Maude hired a young Waterloo attorney, Frederick G. White, to represent Glen in a personal injury suit. In November 1954, on the day Glen's civil suit was to be heard before district court, Schmit's insurance company settled out of court. The Acuffs used the settlement to pay Glen's medical bills. ${ }^{2}$

White did not forget the Acuffs. Early one morning the following spring, he was reading a legal periodical as he rocked his infant daughter. An article about Hitaffer v. Argonne Co., Inc., a 1950 District of Columbia U.S. Court of Appeals decision, caught his attention. ${ }^{3}$ Lucia Hitaffer had successfully brought a loss of consortium claim against her husband's employer to recover damages after her husband suffered a job-related injury due to company negligence. ${ }^{4}$ Loss of consortium is a legal claim brought by a spouse when the other spouse, due to an injury, is unable to provide the full benefits of a marital relationship, including aid, affection, companionship, and sexual relations. ${ }^{5}$ Hitaffer was significant because the court granted a claim to wives that previously had been granted only to husbands. As White read the synopsis of Hitaffer, he wondered if he could make the same claim in Iowa for Maude Acuff. If he won the case, Maude would receive acknowledgment of her loss and, perhaps, compensation. ${ }^{6}$

2. Acuffs interview. White sued for $\$ 57,000$ and claimed that Glen's injuries were the result of Schmit's negligence (failure to yield, traveling at excessive speed, and failure to have his vehicle under control), and that Glen was free of contributory negligence. The liability limits of Schmit's insurance and Schmit's lack of personal assets resulted in a lower settlement. White recalls that the policy limit was about $\$ 10,000$. Frederick $G$. White, telephone interview by authors, 4/7/2009; Waterloo Daily Courier, 9/18/1956.

3. White interview.

4. Hitaffer v. Argonne Co., Inc., 183 F.2d 811 (D.C. Cir. 1950). For a full citation and discussion of the Hitaffer case, see Marilyn Minzer et al., eds., Damages in Tort Actions, 10 vols. (Newark, NJ, 1982), 2:11.02[2][b], which notes that Hitaffer was overruled on other grounds by Smither \& Co., Inc. v. Coles, 242 F.2d 220 (D.C. Cir. 1957).

5. Evans Holbrook, "The Change in the Meaning of Consortium," Michigan Law Review 22 (1923), 2; Directors of The Columbia Law Review Association, "Judicial Treatment of Negligent Invasion of Consortium," Columbia Law Review 61 (1961), 1341; Kevin Lindsey, "A More Equitable Approach to Loss of Spousal Consortium," Iowa Law Review 75 (1990), 714.

6. White interview. 
White, in his third year as a practicing attorney, had almost no trial experience when he read about Hitaffer. He knew it was a brash step for a young and inexperienced attorney to file a previously unrecognized claim. A colleague tried to discourage him, noting that at Drake University Law School he was taught that in Iowa wives could not claim loss of consortium based on negligence. But, as White thought about Hitaffer and researched Iowa law, he could find nothing to prevent him from bringing the claim. He consulted with Wendell Holmes, an experienced attorney he worked with in the county attorney's office. Holmes agreed to sign on to the case as the senior attorney. ${ }^{7}$

The 1956 decision in Acuff v. Schmit, the case filed by White, established a wife's right to claim loss of consortium. Yet the decision rested on a traditional cultural commitment to marriage. Granting the loss of consortium claim to wives did extend married women's legal rights, but it did not represent a fundamental change in the courts' view of the hierarchical relationship between husbands and wives. Case law suggests that judges continued to believe that husbands should support wives and continued to view wives as dependents responsible for the care of children and other family members. The historical evolution of loss of consortium claims exemplifies the significance of marriage in structuring dependence in American society and illustrates the convoluted and sometimes halting process by which the courts aligned the law with changing cultural conceptions of marriage. The survival of the loss of consortium claim in the United States is closely tied to the story of the cultural significance of marriage in mid-twentieth-century America.

THE CLAIM for loss of consortium grew out of coverture, an English common law concept that the American colonies adopted. Under coverture, a woman lost her separate legal identity upon marriage. ${ }^{8}$ The husband and wife were one legal entity under coverture, and the husband represented that legal

7. Ibid.

8. Sir William Blackstone, Blackstone's Commentaries on the Law: From the Abridged Edition of Wm. Hardcastle Browne, ed. Bernard C. Gavit (Washington, DC, 1941), 189-90; Hendrik Hartog, Man and Wife in America: A History (Cambridge, MA, 2000), 115, 298-99. 
entity. The wife was dependent on her husband for economic survival, and the husband was entitled to the wife's services, such as childcare and cooking. ${ }^{9}$ Coverture was fundamental to the legal definition of marriage in the United States.

Marriage was the institution through which the state controlled sexuality, managed labor, and responded to the dependency needs of its citizens. ${ }^{10}$ Because marriage was viewed as a form of governance, husband over wife, cultural conceptions of marriage often reflected the dominant philosophy of political authority. Coverture, which reduced wives to the status of chattel, was similar to the patriarchal paternalism that characterized the English monarch's dominion over the colonies. With the establishment of the republic, people began to view marriage as a contract in which husband and wife freely united for their economic benefit, security, and common interest. However, the hierarchical relationship implicit in the gendered roles of husband and wife did not shift. The legal construct of coverture remained intact. ${ }^{11}$

The claim for loss of consortium emerged in nineteenthcentury U.S. case law as courts sought to compensate a husband for loss of a wife's services following a negligent injury to his wife. ${ }^{12}$ Until Hitaffer in 1950, courts consistently refused to grant wives a similar claim. ${ }^{13}$ Wives had no legal identity under coverture; their husbands represented them in all legal matters. ${ }^{14}$

9. Kathleen Sullivan, Constitutional Context: Women and Rights Discourse in Nineteenth-Century America (Baltimore, 2007), 13-14, 67; Hartog, Man and Wife, 115.

10. Nancy F. Cott, Public Vows: A History of Marriage and the Nation (Cambridge, MA, 2000), 3-8.

11. Ibid., 13-21; Linda K. Kerber, No Constitutional Right to Be Ladies: Women and the Obligations of Citizenship (New York, 1999), 11-15; Joan Williams, Unbending Gender: Why Family and Work Conflict and What to Do About It (New York, 2001), 20-22.

12. Hartog, Man and Wife, 298-99.

13. In 1921, in Hipp v. E. I. Dupont de Nemours \& Co., the North Carolina Supreme Court found that a wife could recover damages following the negligent injury of her husband. Four years later, however, the court reversed itself in Hinnant v. Tide Water Power Company. See discussion of these cases below.

14. Courts generally did not consider wives separate from their husbands, but this rule was not absolute. For example, "if [a wife] committed crimes on her own against others, even if 'by the bare command of her husband,' she was theoretically punishable as if single because her duty to obey the law was 'of a higher nature' than her duty to obey her husband." Hartog, Man and Wife, 108. 
The lack of a legal identity meant that a married woman could not bring her own suit; her husband had to join that suit, and he would receive compensation for any damages assessed. In addition, a husband had a right to his wife's services, but case law did not establish a wife's right to her husband's services. For these reasons, a wife could not make a claim for loss of consortium. ${ }^{15}$

Beginning in the 1830s and continuing through the 1870s, state legislatures passed married women's property acts, which established a wife's separate ownership of the property she brought to the marriage and some of her earnings. These acts also established a wife's right to sue without her husband joining the suit. ${ }^{16}$ Legislatures were primarily interested in shielding a wife's premarital assets from her husband's creditors. ${ }^{17}$ Married women's property acts legally released wives from the patriarchal legal authority of their husbands, provided some economic autonomy, and changed wives' relationship with the state. Nonetheless, judges tended to limit the scope of the statutes; scholars generally agree that the married women's property acts did not result in radical changes for women. ${ }^{18}$

During the first half of the twentieth century, the dominant cultural conception of marriage changed from a patriarchal institution that prioritized economic security and reproduction to a democratic union grounded in romantic love, mutual sexual desire, and emotional fulfillment. Scholars attribute this change in the perception of marriage to several cultural developments. The Victorian idea that middle-class and upper-class white women were passionless gave way to acceptance that sexual desire was natural "among so-called respectable women." The birth control movement offered many married women access to more reliable contraception. The Nineteenth Amendment, passed in 1920, granted women the right to vote, thus acknowledging wives' separate identity and citizenship. These changes

15. Ibid., 115-16, 299; Holbrook, "Change in the Meaning of Consortium," 2.

16. Holbrook, "Change in the Meaning of Consortium," 4.

17. Cott, Public Vows, 52-55; Sullivan, Constitutional Context, 9, 14; Richard Chused, “Married Women's Property Law, 1800-1850," Georgetown Law Journal 71 (1982-1983), 1398-1403.

18. Carole Shammas, "Re-Assessing the Married Women's Property Acts," Journal of Women's History 6 (1994), 9-16. 
meant that wives had the opportunity to express themselves more fully, but they still experienced inequality. ${ }^{19}$

At the same time, the number of women working outside the home increased dramatically as a result of the economic distress of the Great Depression and the labor shortages of World War II. With the exception of the decade between 1910 and 1920, the number of women in Iowa's labor force increased in every decade from 1900 to 1950 . The greatest increase was between 1940 and 1944, when the number of working women increased by 56 percent. In the Acuffs' hometown of Waterloo, the 17 factories that produced war materials employed 14,000 workers, 4,000 of whom were women. ${ }^{20}$

Even as women were increasingly represented in the work force, the paradigm of husband as provider and wife as dependent was entrenched in New Deal public policy. This standard influenced how private and public sector employers viewed and compensated their female employees. ${ }^{21}$ The assumption that a wife's primary responsibilities within a marriage were domestic labor and childcare did not change. ${ }^{22}$

The end of the war renewed the emphasis on a wife's domestic responsibilities. Returning soldiers were anxious to establish themselves as wage earners and heads of households. Many wives who had been employed returned to full-time housewifery either voluntarily or under duress. Following decades of economic and wartime disruption, men and women looked forward to establishing homes that served as comfortable and safe family retreats. ${ }^{23}$ Historian Elaine Tyler May ar-

19. Rebecca L. Davis, “'Not Marriage at All, but Simple Harlotry': The Companionate Marriage Controversy," Journal of American History 94 (2008), 113741; Cott, Public Vows, 157-60; Elaine Tyler May, Homeward Bound: American Families in the Cold War Era (New York, 1988), 40-52.

20. May, Homeward Bound, 40-52; Dorothy Schwieder, Iowa: The Middle Land (Ames, 1996), 281-84.

21. Cott, Public Vows, 157-58, 176-78. Blanche Crozier identified this shift in "Constitutionality of Discrimination Based on Sex," Boston University Legal Review 15 (1935), 748-49.

22. May, Homeward Bound, 59-60.

23. Ibid., 39-90. The shift in attitudes about women's employment is reflected in the meeting programs of the Iowa League of Women Voters. From 1936 through 1940 the league's annual list of priorities included statements about 
gues that for people who had grown up during the Great Depression, the comfort of traditional gender roles was an antidote to the disruption that had characterized their childhood and early adult years. ${ }^{24}$

Employer practices also discouraged wives from working. Employers defined the ideal worker as one who worked fulltime and overtime without time off for childbearing or childrearing. Wives and mothers who needed or chose to work outside the home could not meet such expectations and often found only marginal employment. 25

Consistent with society's changing view of marriage, judges in the twentieth century generally preferred to view marriage as a bond freely entered into and based on love rather than as a contract formed in order to exchange economic support for services. When judges began avoiding the "direct language of service," consortium became a "protean term that suggested the complex yet irreducible qualities of a loving marriage." 26 Under this theory, loss of consortium included loss of "love, affection, companionship, [and] sexual relations." 27 As the definition of loss of consortium changed, the claim's scope, legal significance, and continued existence became uncertain.

Attorney Frederick White recognized an opportunity to expand the claim. He understood the need to develop a distinctive argument that would appeal to the judges who would decide the case; wives had brought loss of consortium claims in many states and lost. White knew that judges were situated in a cul-

expanding employment opportunities: "opposition to all discrimination in public employment based on sex or marital status" $(1936,1937,1939)$ or "removing remaining legal and administrative discrimination which prevents women from having an effective equality with men" (1938). But throughout the late 1940s and 1950s, employment equality disappeared from the league's list of priorities. "Program Record, League of Women Voters 1922-1957," folder: League Publications, 1968-72, box 87, Iowa League of Women Voters Collection, Iowa Women's Archives (IWA), University of Iowa Libraries, Iowa City; Patty Johnson, Women's Editor, "Annual Edition, Waterloo, City of the Future," Waterloo Courier, 12/26/1952, folder 2: Waterloo, 1941-65, box 29, Iowa League of Women Voters Collection, IWA.

24. May, Homeward Bound, 52-53.

25. Williams, Unbending Gender, 1-6.

26. Hartog, Man and Wife, 299.

27. Hitaffer v. Argonne Co., Inc., 183 F.2d 811, 814 (D.C. Cir. 1950). 
ture that understood marriage as a lifelong bond that defined distinct roles for husbands and wives. Many judges focused on the wife's role as a dependent. White decided to argue that a wife's dependence was a reason to allow the claim rather than a reason to deny it. He hoped that the judges would view the case as an opportunity to celebrate and affirm marriage as a partnership. In the 1950s, marriage was the central relationship in most people's lives. People valued marriage for companionship, love, and family. The Acuffs shared these values. White hoped to exploit contemporary cultural values surrounding marriage to support his argument that both husbands and wives should be entitled to make the same legal claims; the law should treat both parties in a marriage similarly.

WHEN Maude McKee and Glen Acuff married on June 28, 1940, they did not question the traditional gendered roles of husband and wife. In 1954 Glen's injury forced them to alter their marital roles. They viewed these changes in their family as an unfortunate exception to the traditional roles of husband and wife. When they agreed that Maude would become a plaintiff in Acuff $v$. Schmit, their hope was that the courts would recognize the irreparable damage to their marriage. They did not think of their claim as an effort to advance gender equality. ${ }^{28}$

As children, Maude and Glen had experienced Depressionera deprivation. Born February 25, 1922, in Cedar Rapids, Iowa, Maude was the oldest of seven children of William and Rose McKee. ${ }^{29}$ When Maude was a child, the McKees purchased an acreage on the edge of Waterloo. In 1931 Rose contracted tuberculosis and was confined for several months to the Oakdale Sanatorium. ${ }^{30}$ During her absence, William juggled caring for his children with working the third shift at John Deere Manufacturing. On the day Rose returned home, her exhausted husband was hospitalized with pneumonia. He died two days later.

28. Acuffs interview.

29. “Obituaries-Maude L. Acuff 1922-2010," WCF Courier.com, 8/22/2010, http:/ / wcfcourier.com/lifestyles/announcements/obituaries/maude-l-acuff/ article_5fb558ae-ac9c-11df-b9cf-001cc4c002e0.html.

30. Kate Caughron (Maude Acuff's sister), interview by Joy Smith, Waterloo, $10 / 24 / 2011$. 
Maude was ten years old. Unable to make mortgage payments, the family lost their home and moved to a series of rental homes in northeast Waterloo. When Maude was 15, she quit high school and began cleaning houses in order to supplement the family's income. ${ }^{31}$

One year before her father's death, Maude was attending a Salvation Army worship service with her friend when two unfamiliar boys walked into the church. She remembered joking to her friend, "Oh my gosh, there's some new guys coming in. I'll tell you what. I'll marry the taller one and you marry the other one." The "taller one" was Glen Robert Acuff. Two years older than Maude, Glen had been born September 14, 1920, on a farm near Sumner, Iowa, to Lloyd William and Drucie Bower Acuff. At some point, Lloyd left his family. Drucie raised Glen and his two brothers on the farm, eventually remarrying. ${ }^{32}$

On June 28, 1940, Maude did marry Glen. Their oldest son was born the following year. Not long after, Glen enlisted in the U.S. Navy. Following the war, the Acuffs had three children in quick succession and moved to an acreage southwest of Waterloo. Glen worked for a time at John Deere Tractor Works and at Chamberlain Manufacturing before taking the construction job he held at the time of the accident. ${ }^{33}$

For young men like Glen who returned from the war anxious to put down roots and start a family, Waterloo offered numerous opportunities for employment at a decent wage. Located in northeast Iowa and the county seat of Black Hawk County, Waterloo in 1950 was a vibrant community of 65,000 with an economy based in heavy industry. The city experienced a 26 percent population increase between 1940 and 1950. In 1954 there were 134 manufacturing concerns in the city. The two largest, Rath Packing and John Deere Tractor Works, each employed more than 7,000 workers. ${ }^{34}$

31. Caughron interview; Acuffs interview.

32. Acuffs interview; Waterloo-Cedar Falls Courier, 4/29/1996; Caughron interview.

33. Acuffs interview.

34. 1950 Census of Population: Volume 2, Characteristics of Population: Part 15, Iowa (Washington DC, 1952), 15-18; Waterloo Iowa Centennial 1854-1954: Prairidrama, Souvenir Program, 33; Glenda Riley, Cities on the Cedar: A Portrait of Cedar Falls, Waterloo, and Black Hawk County (Parkersburg, IA, 1988), 59-73. 
Like many women of her era, Maude took on and probably looked forward to the roles of housewife and mother. Glen was the breadwinner and head of the household. Maude was responsible for the work of the family: housekeeping, caring for their children, and creating a welcoming, stable home environment. ${ }^{35}$

The Salvation Army was the center of Maude and Glen's social and religious life. When Maude was a little girl, shortly after the family moved to Waterloo, neighbors invited her parents to join "The Army." When William died, the church offered spiritual and financial sustenance to Rose. Glen's first experience in the church came at the invitation of a boyhood friend. As a young married couple, Glen and Maude assumed leadership responsibilities in the church: Glen was a favorite Sunday school teacher of older teens and adults; and Maude led the Girl Guards, served as the Sunday school secretary, sang in the Songster Brigade, and sold copies of War Cry, the church magazine. Before the accident, Glen and Maude had planned to train as officers, the church's form of ministry. ${ }^{36}$ Many Americans think of the Salvation Army as a Christian social service agency, but historian Lillian Taiz notes that urban workingclass families were drawn to the locally controlled nondenominational missions because they offered opportunities for usefulness and leadership and a sense of community. ${ }^{37}$

On the day of his accident, Glen was on his way home from work to clean up before returning to Waterloo to attend a dinner at the church with his family. News of the accident spread quickly through the church community. Members immediately came to the Acuffs' aid, providing Maude with childcare, trans-

\section{Acuffs interview.}

36. Maude and Glen's youngest daughter and her husband later became officers, and many members of the extended family remain active with the Salvation Army. Information about Acuff family involvement with the Salvation Army is from Fred Acuff, e-mail to author, 3/30/2009.

37. While dominated by the working class, the Salvation Army always attracted some educated middle-class members. Beginning in the 1930s, these members began to push for a centralized hierarchical church structure, modulation of religious expression, and a social work paradigm. Although the middle-class agenda ultimately prevailed, Salvation Army members continued to reject consumerism and materialism. Lillian Taiz, Hallelujah Lads and Lasses: Remaking the Salvation Army in America, 1880-1930 (Chapel Hill, NC, 2001), 1-10, 167. 


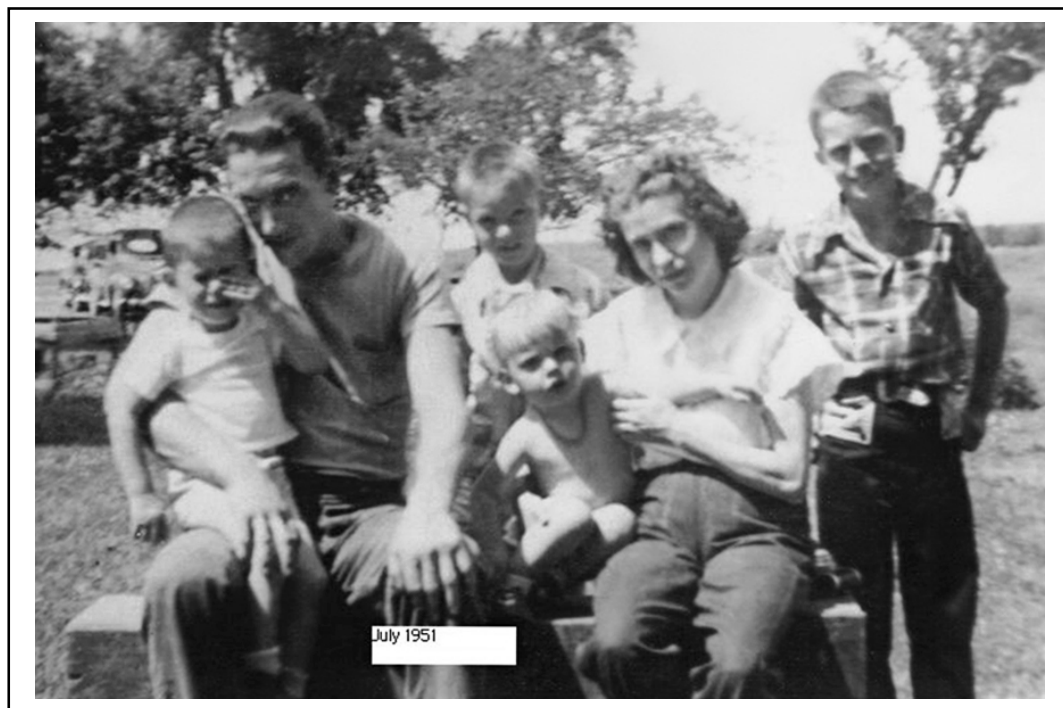

The Acuff family before Glen's accident, summer 1951. From left to right, Fred, Glen, Kenny, Judy, Maude, and Billy. Photo courtesy Fred Acuff.

sportation, and lodging near the Iowa City Veterans Hospital, where Glen was hospitalized. In the difficult months and years that followed, the family received material assistance and gained spiritual strength from the Salvation Army. ${ }^{38}$

Paralyzed as a result of his spinal cord injury, Glen was discharged from the hospital after five months. Maude and her sons assumed responsibility for all of Glen's personal care and mobility needs. They learned to transfer Glen from bed to chair to car. Glen painfully "pounded" and exercised his arms and hands daily to recover some function of his upper extremities. Slowly, he learned to live with his disabilities, but he could no longer support his family financially. For the first year or two, the family survived on the meager public assistance allowance, supplemented by help from family and church. ${ }^{39}$

38. Acuffs interview; Caughron interview.

39. Acuffs interview. Fred Acuff remembers that the family received government food commodities but that there were times when there was no food in the house. He recalls that the family received $\$ 165$ per month in assistance. Acuffs interview. This amount is consistent with aid payments at the time. In 1943 the Iowa legislature passed the Aid to Dependent Children Act, which 
Maude realized that something had to change. In the early winter of 1955 she suggested to Glen that she get a job. She wanted to answer a newspaper ad for seasonal help wrapping specialty gifts for Santa Claus Industries. At first Glen resisted, insisting that it was his place to support the family. Maude gently persisted, convincing Glen that with her earnings from this temporary job they would be able to "give the kids a Christmas." The company liked Maude's work, and the temporary job became permanent. ${ }^{40}$

In the summer of 1955, a few months before Maude was hired at Santa Claus Industries, Frederick White approached the Acuffs regarding the possibility of filing the loss of consortium claim on Maude's behalf. The couple needed any financial award a suit might bring. They also sought recognition of the damage their family had suffered. They trusted White and decided to bring the suit. ${ }^{41}$

BORN IN 1928, White was the first in his family to study law. His father was the general foreman of shipping at Rath Packing Company in Waterloo. The senior Mr. White had taken a job as a laborer at Rath after his father had lost the family farm in the recession of 1919-1920. White's mother eventually worked as a saleswoman, but when White was young she worked as a housewife and cared for White and his two brothers. Like many young men of his generation, White joined the military upon high school graduation; in December 1944 he enlisted in the Army Air Corps, where he trained as a cryptographer. Following the

was designed to provide assistance to needy children under the age of 18 who were regularly attending school, living with a family member, and who were deprived of parental support and care due to the death, continued absence from home, or physical or mental incapacity of either parent. The 56th General Assembly (1955-56) passed an amendment that limited assistance to any family to $\$ 175$ per month. The constitutionality of this amendment was successfully challenged in 1957. In a decision written by Chief Justice Norman Hays, who also wrote the decision in Acuff, the court ruled that the amendment unfairly discriminated among dependent children because the original law granted assistance to individual children, and the amendment varied the amount of assistance received by each child based on the number of children in their family. Collins v. State Bd. of Soc. Welfare, 81 N.W.2d 4, 6-9 (Iowa 1957).

40. Acuffs interview.

41. Ibid. 
war, he returned to his hometown and a job at Rath skinning calves and boning lamb and veal. He soon took advantage of the GI Bill to enroll at Iowa State Teachers College in neighboring Cedar Falls. A year-and-a-half into his studies, encouraged by one of his professors, White transferred to the University of Chicago and enrolled in a four-year program that offered a combined law and liberal arts degree. He earned a J.D. degree in 1951.42

The curriculum at the University of Chicago Law School was unusual. When the Law School was founded in 1902, University President William Rainey Harper advocated for the "wholeness of the institution," emphasizing the importance of closely connecting the law school with the liberal arts departments, including history, sociology, and political science. Harper's insistence on an integrative approach led to lively debate among faculty, some arguing that reducing the time for studying pure law, even for third-year students, was unthinkable. 43 Although the combined degree was discontinued during White's years in the program, aspects of the cross-disciplinary curriculum survived. White recalls that professors from history, economics, and other social sciences regularly delivered lectures in his law classes. ${ }^{4}$

White's Chicago training prepared him for the trial and appellate work that dominated his career during the 50 years he practiced general law in northeast Iowa. The integrated coursework taught him to reason historically about the law. His ex-

42. White interview.

43. Frank Ellsworth, Law on the Midway: The Founding of the University of Chicago Law School (Chicago, 1977), 50-69. Law school curricula typically followed a model of professional education established in the late nineteenth century by Professor C. C. Langdell at Harvard University. Langdell advanced the idea of an academic meritocracy requiring a bachelor's degree for admission, establishing a sequential three-year curriculum, and using the case method of pedagogy. "The Harvard position was the traditional one taken by the few law schools which had considered the issue. Subjects related to the liberal arts did not belong in legal education, and those deemed slightly questionable were assigned to seminars." Ellsworth, Law on the Midway, 69. For an extensive discussion of Langdell's influence on professional pedagogy, see Bruce A. Kimball, The Inception of Modern Professional Education: C. C. Langdell (Chapel Hill, NC, 2009).

44. White interview. 


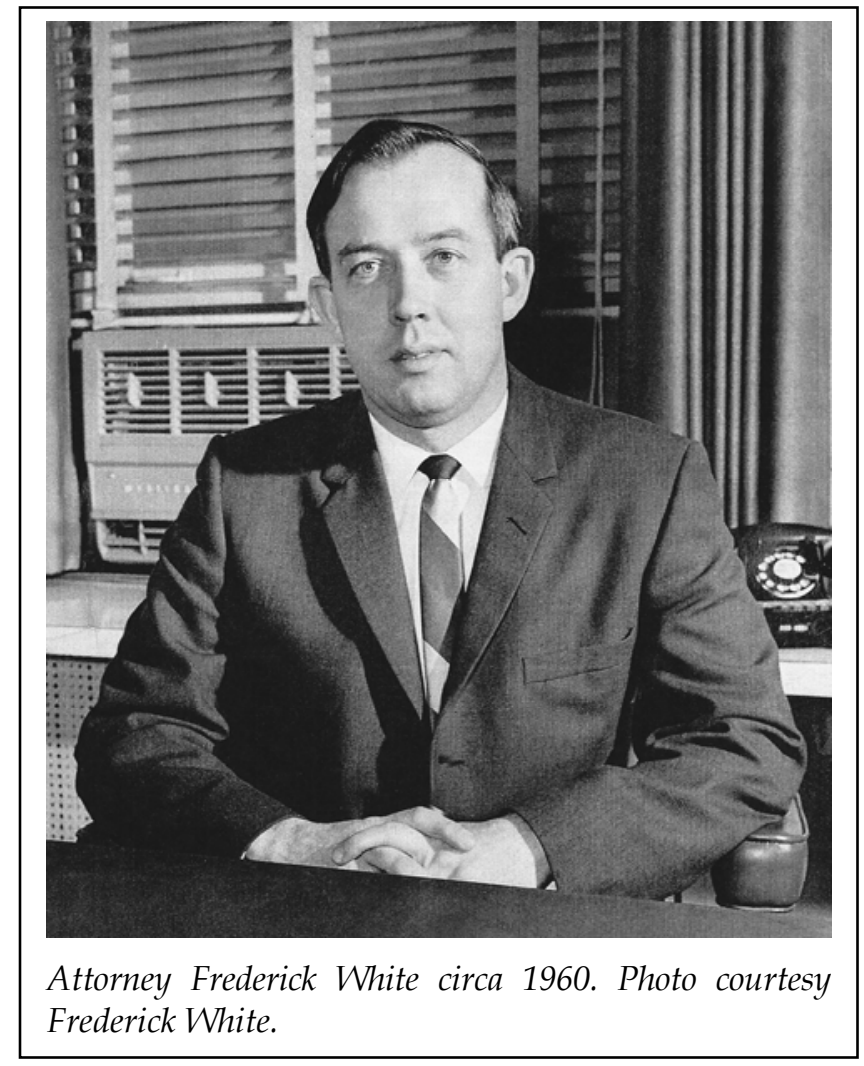

perience on the school's nationally competitive debate and moot court teams trained him to shape a persuasive argument. Certainly his intellect was honed by interaction with capable and motivated classmates, several of whom would develop national reputations in politics and law: his classmates included Ramsey Clark, who would serve as U.S. attorney general during the Johnson administration; future members of Congress Abner Mikva and Patsy Mink; and failed U.S. Supreme Court nominee and Yale law professor Robert Bork. ${ }^{45}$

Although White thrived in the challenging academic arena at the University of Chicago, he did not lose touch with his working-class roots. Unable to locate a job as a lawyer following graduation, he returned to the factory floor at Rath for a brief

45. Ibid. 
time. He then sold insurance for a few months before deciding that if he was ever going to practice law he should start. In March 1952 he rented office space in his hometown, borrowed his mother's old dining room chairs, acquired a portable typewriter, and opened his law practice. In the summer of 1953 he married; by the spring of 1955, when he read Hitaffer and began considering filing a loss of consortium case on behalf of Maude Acuff, he was a young parent, probably sensitive to how the loss of a male breadwinner could seriously jeopardize a family's security. ${ }^{46}$

White filed Acuff v. Schmit in Black Hawk County District Court on July 9, 1955, before Judge George Heath. Based on decades of precedent that had denied a wife the right to claim loss of consortium, defense attorneys Glenn Beers and R. Bruce Hughes argued for dismissal. ${ }^{47}$ Judge Heath, according to White, could not understand his argument. White remembers Heath as a good judge and a conservative man whose thinking about a wife's right to the loss of consortium claim was entrenched in the reasoning that had prevailed in earlier decisions. ${ }^{48}$ Judge Heath dismissed the case. ${ }^{49}$ White was not deterred. He believed in his argument and felt that there was nothing to lose on appeal. On October 20, 1955, he filed a note of appeal to the Iowa Supreme Court. He began the arduous task of researching the convoluted history of coverture and loss of consortium in case law and carefully drafting his brief. ${ }^{50}$

COURTS defined the claim for loss of consortium in various ways after its emergence in nineteenth-century case law. White spent several months tracing those developments. The married

46. Ibid.

47. Petition at Law, Motion to Dismiss, Acuff v. Schmit, 248 Iowa 272 (Iowa 1956) (No. 10-48939), 7-8. Glenn Beers, the senior defense attorney, is deceased. R. Bruce Hughes, who prepared the appellee's brief, later moved to San Francisco. White interview.

48. White interview; Frederick G. White, telephone interview with Hoey, 11/11/ 2011.

49. Petition at Law, Ruling on Motion, Acuff v. Schmit, 248 Iowa 272 (Iowa 1956) (No. 10-48939), 9.

50. Petition at Law, Notice of Appeal, Acuff v. Schmit, 248 Iowa 272 (Iowa 1956) (No. 10-48939), 9. At the time, White was also employed as an assistant county attorney. White interview. 
women's property acts enacted in the mid-nineteenth century granted wives the right to bring independent legal claims, but judges had a variety of concerns that caused them to limit the scope of those acts. Judges concluded that wives could bring loss of consortium suits when a defendant intentionally interfered with the marital relationship, as in alienation of affection cases, but they consistently refused to find that the married women's property acts entitled a wife to a claim for loss of consortium following a negligent injury to her husband. ${ }^{51}$

The possibility of double recovery in loss of consortium cases based on negligence concerned many judges. ${ }^{52}$ They believed that differences between the roles of husbands and wives required different treatment. They reasoned that double recovery could occur in one scenario but not in a second. In the first scenario, a husband is injured and both husband and wife sue. The wife receives compensation for her loss of consortium. The husband receives compensation for his injuries and for the loss of his ability to support his wife. In the second scenario, a wife is injured and both husband and wife sue. The husband receives compensation for his loss of consortium. The wife receives compensation for her injuries. However, the wife does not receive compensation for any lost ability to support her husband because she has no obligation to support him. Double recovery occurs in the first scenario because the wife recovers for the same loss twice; she receives a loss of consortium award, and she also benefits from her husband's award for the lost ability to support her. Double recovery does not occur in the second scenario. Double recovery also could not occur in cases where the loss of consortium claim was based on intentional interference with the marriage because in those cases the husband "was a joint wrongdoer with the defendant" and therefore could have no cause of action against the defendant. Based on these concerns, which were still grounded in the legal status of the wife as a dependent under coverture, judges rejected loss of

51. White interview; Hartog, Man and Wife, 298-99; Cott, Private Vows, 52-55, 168-69; Holbrook, "Change in the Meaning of Consortium," 4-6; Sullivan, Constitutional Context, 69; Hitaffer, 183 F.2d at 816 n.30 (listing cases).

52. Leon Green et al., Cases on Injuries to Relations (St. Paul, 1968), 245. 
consortium claims brought by wives whose husbands had been negligently injured. ${ }^{53}$

Courts rejected a wife's loss of consortium claim based on negligence for other reasons as well. For example, some courts said the claim of loss of consortium was based in loss of services, and because the wife had no claim to her husband's services she could not recover. ${ }^{54}$ Other courts denied wives the claim, finding that wives did not have property rights. ${ }^{55}$ Courts also argued that the wife's injury was too indirect or remote to measure and expressed concern that children and other people might be able to recover for loss of consortium if the claim was extended to wives. ${ }^{56}$ Because wives and children were both dependents under the law, some judges likely believed that such an expansion of the claim was a strong possibility. ${ }^{57}$

Believing that they could not create what they considered a new cause of action without relying on a statute or other authority, courts indicated that legislatures could create a cause of action for wives if they considered it necessary. ${ }^{58}$ Even though courts stated that they recognized the unfairness of allowing a husband a cause of action while denying a wife the same cause of action, they claimed that they were not in a role to resolve problems of gender inequality and other social issues. ${ }^{59}$ In at-

53. Hitaffer, 183 F.2d at 814; Evans Holbrook, "Change in the Meaning of Consortium," 6.

54. Hitaffer, 183 F.2d at 813 (citing cases, including Stout v. Kansas City Terminal Ry. Co., 157 S.W. 1019, 1022 [Mo. App. 1913]). In 1963 the Missouri Supreme Court decided that Stout should not be followed. See Novak v. Kansas City Transit, Inc., 365 S.W.2d 539, 544-45 (Mo. 1963).

55. Ibid., 815 (citing cases, including Stout, 157 S.W. at 1021).

56. "Judicial Treatment of Negligent Invasion of Consortium," Columbia Law Review 61 (1961), 1350, 1355; Hitaffer, 183 F.2d at 815.

57. Hartog, Man and Wife, 193.

58. Hitaffer, 183 F.2d at 814 (citing cases, including Stout, 147 S.W. at 1021, where the court noted that "the entire damage in cases of negligent injury to a husband or father has always been considered as centering in him ... and a settlement with him has always been recognized as closing the incident"); "Judicial Treatment of Negligent Invasion of Consortium," 1350, 1352.

59. See Ripley v. Ewell, 61 So.2d 420, 423 (Fla. 1952): “We have given careful consideration to the able arguments advanced in the Hitaffer case, many of which are founded on sound reasoning and which logically support the conclusion reached if considered as an argument of what the law should be. They 
tempting to avoid the issues, they allowed unjust principles to remain embedded in the law.

Courts sometimes found arguments about equal treatment persuasive and decided that neither the husband nor the wife could recover for loss of consortium. ${ }^{60}$ Nearly 30 years before Hitaffer, the North Carolina Supreme Court issued a series of rulings on loss of consortium that highlighted equal-treatment arguments. In 1921 the North Carolina Supreme Court rejected arguments regarding concerns over expanding liability and found that a wife could recover for loss of consortium. ${ }^{61}$ That decision was the first to allow a wife to recover for loss of consortium based on negligence. ${ }^{62}$ The court overruled that decision in 1925, finding that the wife's "mental anguish" alone could not entitle her to compensation. ${ }^{63}$ In 1945 the court decided that neither the wife nor the husband could recover for loss of consortium, reasoning that this result treated the parties equally. ${ }^{64}$

Concern about compensation for emotional harm likely influenced some judges considering loss of consortium cases. The husband's action for loss of consortium grew out of his entitlement to his wife's services. Because a wife could not point to

might well appeal to the Legislature. But we find them wholly unconvincing when viewed from the only angle from which our jurisdiction permits us to consider them, namely, a determination of what the law of Florida is." The Florida Supreme Court changed course in 1971, finding that a wife had a derivative right to loss of consortium and stating that the "the recent changes in the legal and societal status of women in our society forces us to recognize a change in the doctrine with which this opinion is concerned." See Gates v. Foley, 247 So.2d 40, 44-45 (Fla. 1971).

60. Hitaffer, 183 F.2d at 813 n.11 (citing cases, including Marri v. Stamford St. R. Co., 78 A. 582, 587 [Conn. 1911], where the court said it was "of the opinion that the reason for the former rule no longer exists, and that it should cease to have recognition." The Connecticut Supreme Court overruled Marri in 1979. See Hopson v. St. Mary's Hospital, 408 A.2d 260 (Conn. 1979).

61. Hitaffer, 183 F.2d at 813; Hipp v. E. I. Dupont de Nemours E Co., 108 S.E. 318, 323 (N.C. 1921), overruled by Hinnant v. Tide Water Power Co., 126 S.E. 307, 312 (N.C. 1925).

62. Hitaffer, 183 F.2d at 813.

63. Ibid.; Hinnant v. Tide Water Power Co., 126 S.E. 307, 312 (N.C. 1925), overruled by Helmstetler v. Duke Power Co., 32 S.E.2d 611, 612-14 (N.C. 1945).

64. Helmstetler v. Duke Power Co., 32 S.E.2d 611, 612-14 (N.C. 1945), overruled by Nicholson v. Hugh Chatham Memorial Hospital, 266 S.E.2d 818 (N.C. 1980); Hitaffer, 183 F.2d at 813 n.7. 
any similar entitlement, her claim could be framed as one for purely emotional distress, as it was by the North Carolina Supreme Court in 1925. Some court decisions likely reflected discomfort with compensating emotional harm. In fact, debate over whether and how to compensate for emotional harm continues today. In the 1950s disruptions in marital relationships likely affected wives more than husbands; wives were often separated from their extended families and lacked the social connections husbands built through work. ${ }^{65}$

With the exception of the briefly held 1921 decision of the North Carolina Supreme Court, no court found a wife entitled to loss of consortium based on negligence until 1950, when the District of Columbia Circuit Court decided Hitaffer v. Argonne Co. Inc., the case that captured White's attention as he comforted his infant daughter on the spring morning in 1955. ${ }^{66}$ The Hitaffer court noted that an action for loss of consortium was not based primarily in loss of services but in loss of a relationship. The court stated that many reasons for denying recovery were illogical because they applied equally in suits where the husband sued. According to the court, "simple mathematics" could solve any potential problem with double recovery. A court could subtract from the wife's award the amount the husband had recovered for his obligation to support his wife. The Hitaffer court believed that judges who denied recovery relied on "medieval concepts of the marriage relation." 67

The Hitaffer court saw itself as describing a new understanding of marriage.

It can hardly be said that a wife has less of an interest in the marriage relation than does the husband or in these modern times that a husband renders services of such a different character to the family and household that they must be measured by a standard

65. Martha Chamallas and Jennifer Wriggins, in The Measure of Injury (New York, 2010), 2-3, identify "the recent trend toward eliminating or curtailing noneconomic damages." They argue that "the marginalizing of emotional harm and noneconomic injury has worked to the systematic disadvantage of women and minority plaintiffs, who may find that the most serious recurring injuries in their lives are not compensable in tort." See below for a discussion of wives and their extended family ties.

66. Minzer et al., eds., Damages in Tort Actions, 2:11.02[2][b].

67. Hitaffer, 183 F.2d at 814-15, 819. 
of such uncertainty that the law cannot estimate any loss thereof. The husband owes the same degree of love, affection, felicity, etc., to the wife as she to him. He also owes the material service of support, but above and beyond that he renders other services as his mate's helper in her duties, as advisor and counselor, etc.

Marriage was a partnership, according to the court, in which each partner contributed equally valuable services. The husband's contribution to the relationship was not purely financial but also involved emotional support and friendship. ${ }^{68}$

The Hitaffer decision reflected the understanding of marriage in the 1950s and the celebration of marriage as the primary emotional relationship in people's lives. So many people married in the 1940s and 1950s that "forging an independent life outside marriage carried enormous risks of emotional and economic hardship, along with social ostracism." 69 In addition, as Nancy Cott notes, in the 1940s marriage was "seen as more companionate, more flexibly defined, [and] less hierarchically structured than in the past."70 Because the Hitaffer court saw marriage as a partnership based on love, denying wives the loss of consortium claim was denying its vision of marriage as partnership.

Despite its focus on marriage as a partnership, the Hitaffer court did not directly challenge the inequalities present in the prevailing structure of marriage. Instead, it emphasized each partner's valuable contributions to the relationship. Each partner had distinct roles, but the roles for each were significant and worthy of public support and recognition. The Hitaffer court did not question these separate roles. In its view, allowing a wife to bring a loss of consortium claim publicly recognized the love and affection present in marriage and strengthened the emotional commitment between husband and wife. It affirmed, rather than challenged, traditional marital roles. When Frederick White appealed Judge Heath's decision to the Iowa Supreme Court, he was able to look to Hitaffer as a model for structuring his arguments in a way that would appeal to the cultural values of the Iowa Supreme Court justices.

68. Ibid., 819.

69. May, Homeward Bound, 3-5, 38.

70. Cott, Public Vows, 181. 
THE NINE Iowa Supreme Court justices who decided Acuff in 1956 reflected the majority of the citizenry that elected them. ${ }^{71}$ All men, the justices ranged in age from 50 to 86, all but one born in the nineteenth century. All were Republicans; all were married with children; six of the nine identified as Protestant. All but one graduated from an Iowa law school. The exception, Norman R. Hays, who wrote for the majority in Acuff v. Schmit, graduated from Harvard Law School. The judges' average length of service on the court at the time they decided Acuff $v$. Schmit was 9.6 years. ${ }^{72}$

Although active political party involvement was a prerequisite for election to the bench, evidence suggests that most judges

71. Except for a period between 1913 and 1918 when judges were elected on a nonpartisan basis, Iowa judges were elected in partisan general elections. That changed in 1962, when Iowa voters ratified a constitutional amendment that established gubernatorial appointment of district and supreme court justices from a list of nominees advanced by a nominating commission composed of lay persons and lawyers. In the first year following their appointment and then every eighth year, supreme court justices stand for retention during the general election. This process, still in place in Iowa, was intended to ensure the professional competence of justices and raise the selection process above partisan politics. The Judicial Department, Iowa's Third Branch (Des Moines, 1984), 2-3. The effectiveness of the reform in keeping partisan politics out of judicial selection was tested in the 2010 and 2012 general elections. Grant Schulte, "Iowans Dismiss Three Justices," Des Moines Register, 11/3/2010; A. G. Sulzberger, "Ouster of Iowa Judges Sends Signal to Bench," New York Times, 11/3/2010; Jeff Eckhoff, "Voters Retain Justice Wiggins," Des Moines Register, $11 / 12 / 2012$.

72. Judges on the Acuff Court were Norman R. Hays, William L. Bliss, Theodore G. Garfield, Robert L. Larson, and W. A. Smith for the majority; Oliver W. Lawrence, Henry Kaare Peterson, G. K. Thompson, and Charles F. Wennestrum dissenting. Iowa Judicial Branch, "Public Information>Iowa Court's History>Past Iowa Supreme Court Justices," http://www.iowacourts.gov/ Public_Information/Iowa_Courts_History/Past_Iowa_Supreme_Court_Justices/ (last accessed 11/13/2011); Edward N. Dodge, ed., Business Men of Iowa: A Biographical Cross Section of Commercial Financial, Industrial, Professional, and Agricultural and Public Life within the State 1953 (Des Moines, 1953), 61, 240, 301, $326,421,554,580,683,726,773$ (this publication identifies six of the justices as Protestant but does not indicate a religious preference for the other three justices); Justice Robert L. Larson to President Millard G. Roberts, Parsons College, 12/23/1955, file: Correspondence 1950-62, box 2: Speeches 1953-1971, Correspondence Personal 1950-60, Robert L. Larson Collection, State Historial Society of Iowa, Iowa City (hereafter cited as Larson Collection); Lawrence Kestenbaum, "William L. Bliss," Political Graveyard.com Index to Politicians, http:/ / politicalgraveyard .com/bio/blight-block.html\#555.20.98 (last accessed 11/6/2011). 
were motivated by a sense of public service and a commitment to the rule of law rather than by political power. Chief Justice Norman R. Hays came from a family of lawyers and was a county attorney and a district judge before his appointment to the Iowa Supreme Court in 1946. A grandson who was raised by Judge Hays remembers him as passionate about politics and a "news junkie," a sociable but reserved man who was respectful of others and never raised his voice at his wife. ${ }^{73}$ Before his appointment to the state's highest court, Justice Robert L. Larson had served as attorney for Iowa City and Johnson County and as state attorney general. He spoke widely to civic groups on a range of topics related to citizenship and the rule of law. In a letter to the president of Parsons College, his undergraduate alma mater, he summed up his public service. "My main interest is the welfare of my fellowmen, and [I] have concentrated my efforts to get everyone to respect and obey the laws of our state and nation, as well as God's superior laws; to respect one another's rights as individuals as well as fellow-citizens and to help others help themselves." 74

Salaries were modest, and the justices received minimal compensation for expenses. Attorney White recalled that some justices slept in the back of the courtroom when the court was in session..$^{75}$ In 1960 Judge Larson described this arrangement.

It's a rather antique setup . . . and it has been there ... . ever since the State house was built. Originally the judges and their wives stayed in those cubbyholes [small rooms behind the conference rooms which were adjacent to the courtroom] and they cooked and lived there regularly. Of course as the court grew from three to five, and then to seven, such quarters were not adequate. Now the rooms behind the conference rooms have become offices and sleeping quarters, with cots, desks and books. When I joined the

73. Knoxville Journal, 9/9/1946; Lorin Nelson "Larry" Hays IV, e-mail to Joy Smith, 6/2/2011. Judge Hays's father, Lorin Nelson Hays, and his uncle, E. R. Hays, moved to Knoxville, Iowa, from Fostoria, Ohio, in the decade following the Civil War and established a law practice. Hays's uncle served a term in the U.S. House of Representatives, and his father was elected to the state legislature in 1879 and as a district judge in 1911. Hays, e-mail to Smith.

74. Robert L. Larson to Millard G. Roberts, 12/12/1955, file: Correspondence 1950-62, box 2, Larson Collection.

75. White interview. 
court, all but about one or two members of the court slept there. Now only four do so. The rest of us live in hotels while we are in session at Des Moines. ${ }^{76}$

Justice Hays's grandson recalled that when the court was in session his grandmother would drive his grandfather to Des Moines, where he would live for the week in the old Kirkwood Hotel. "Others always assumed that a Supreme Court Justice made a lot of money, but they didn't. [Grandpa] retired without much in the way of benefits and left only a small estate." 77

Although the court gradually made procedural changes in response to the demands of a growing docket of cases, the court's routine grew out of decades of tradition. The court convened in the State Capitol in Des Moines for one week of each month except July and August. Monday was reserved for judicial conference. On the remaining days of the week the justices typically heard six cases each day. The mantle of chief justice rotated among the judges, with each judge serving a six-month term. ${ }^{78}$ Responsibility for writing opinions was also assigned on a rotating basis. Each day closed with an informal conference when the judges shared preliminary views. At the end of a week-long session the judges returned to their hometowns for the remainder of the month to research and write opinions. Once drafted, mimeographed copies of opinions were circulated by mail. Formal concurrences were sent to the author of an opinion. If a judge did not concur with an opinion, he wrote and circulated a dissenting opinion. At the Monday conference the following month the judges formally voted on each decision, indicating concurrence or dissent. If there were conflicting views, a case might be held over to allow time for both sides to

76. Robert L. Larson, "Speech to Appellate Practice Class," 4/19/1960, folder: Speeches, box 2, Larson Collection.

77. Hays, e-mail to Smith.

78. In 1960 the Iowa legislature directed a shift to a permanent chief justice elected by the justices. Judge Larson was the first person elected to this position. Larson, "Speech to Appellate Practice Class." A letter of congratulations on Judge Larson's appointment as the court's first permanent chief justice, from Clarence Kading, the Judicial Department statistician, alludes to Larson's salary increase to $\$ 14,500$. Clarence A. Kading to Robert L. Larson, 11/9/1960, file: Correspondence 1950-62, box 2, Larson Collection. 
present their views and modify their opinions to gain more support. 79

The court did not require oral arguments, but an attorney's ability to craft and present an argument could significantly influence the court's opinion. The justice assigned to write the opinion read the case briefs the night before the hearing. One or two other justices might read the briefs in advance, but most had little familiarity with a case before it was heard. The appellant was allowed 30 minutes to present the case and 15 minutes on reply. The ability to briefly state the facts of the case, clearly articulate the questions of law, and persuasively and concisely present an argument was important. In a speech to a group of law students, Judge Larson emphasized the importance of oral argument.

You have the nine member court passing on your case-not just one or two judges especially interested in your problem. If you should do a poor job of arguing orally or, by repetition, put the members to sleep, they probably won't know enough about your case when it is written to take issue with the judge who wrote the opinion, and it may go through without close scrutiny of several members of the court. ${ }^{80}$

Frederick White's University of Chicago moot court experience had taught him the importance of a carefully honed oral argument. He was prepared to capture the judges' attention. ${ }^{81}$

RESPONSIVENESS to questions of equality and civil rights is a hallmark of the Iowa Supreme Court. In the first case to come before the Iowa Territorial Court, In Re the matter of Ralph 1839, the court determined that Ralph, a slave working in the lead mines near Dubuque under a written agreement with his Missouri owner, could not be forced to return to slavery in Missouri when he failed to purchase his freedom. The ruling stated that "'no man in this territory can be reduced to slavery.'" In Clark v. The Board of Directors, decided in 1868, the court found that

79. Larson, "Speech to Appellate Practice Class."

80. Ibid.

81. White interview. 
segregated schools were fundamentally unequal. The ruling directed that a 12-year-old African American girl be admitted to her neighborhood school, stating that "the law makes no distinction as to the right of children ... to attend the public schools.'" Emma Coger, an African American woman who had been removed from a steamboat dining room, was granted the same rights and privileges as white passengers in the 1873 case, Coger v. The North Western Union Packet Co. In 1869 the Iowa Supreme Court was the first court in the nation to admit a woman, Arabella A. Mansfield, to the practice of law. In State v. Walker (1921), the court was one of the first in the nation to reason that the Nineteenth Amendment made women eligible for jury service. ${ }^{82}$

Frederick White hoped to extend the court's record of affirming civil rights. His challenge was to convince the court that the concept of loss of consortium remained valid while arguing that the justices should reject the structure of coverture, which provided the basis for the claim. If he overemphasized equality between husband and wife, the court could decide that neither husband nor wife could recover for loss of consortium. Maude would then not recover for her loss. In that context, White did not argue for a radical redefinition of gender roles in marriage. He focused on the love and affection in marriage and argued that each partner had equal rights to that love and affection. That argument was consistent with the Hitaffer court's reasoning and the understanding of marriage in the 1950s.

In his brief, White emphasized the court's opportunity to change an unjust law. He first sought to establish that a husband in Iowa could recover for loss of consortium based on negligence. In doing so, White cited older cases based in the common law that emphasized affection and love in marriage. ${ }^{83}$ In this way, White focused on affirming the central role of marriage in society.

82. “Iowa Judicial Branch: Early Civil Rights Cases," http://www.iowacourts online.org/Public_Information/Iowa_Courts_History/Civil_Rights/index.asp (last accessed 10/26/2011); Brief for Mark E. Schantz et al. as Amici Curiae Supporting Plaintiff-Appellees, Varnum v. Brien, 763 N.W.2d 862 (Iowa 2009) (No. 07-1499).

83. Appellant's Brief and Argument, Acuff v. Schmit, 248 Iowa 272 (Iowa 1956) (No. 10-48939), 10-11, 18, 20. 
White opened his argument by stating that the case was "a case of first impression," which meant that the Iowa Supreme Court had not yet decided whether a wife could bring a loss of consortium claim based on negligence. He presented the case as an opportunity for the judges to affirm the cultural understanding of marriage at that time and declare coverture dead. White stated that all reasons for denying wives the claim went "back to an era when a husband was not only lord and master of his household but was the only medium through which his wife could enter the courts." White painted the past as a barbaric time and the present as an enlightened era. ${ }^{84}$

White was careful not to challenge the institution of marriage itself or the roles within marriage. In fact, White stated that the married women's property acts did not change the nature of the duties of husband and wife. Instead, he said, those acts were evidence that legislatures intended for men and women to have equal rights before the law. Equal legal rights would not entail restructuring the marital relationship; husbands and wives would maintain distinct roles. 85

White made it clear that allowing wives to bring loss of consortium claims based in negligence would affirm the marital relationship. He quoted from a previous Iowa Supreme Court decision that described the nature of marriage: “"The marriage state is not one entered into for the purposes of labor and support alone. Considerations of the highest character, as the comfort and happiness of the parties ... give to each the right to the affection, companionship, and society of the other." "86 White deemphasized the economics of marriage and highlighted the social and relational aspects of marriage. That strategy avoided highlighting any possible disruption to marital roles and duties that giving wives the cause of action might create. White's strategy also stressed the ability of the loss of consortium award to affirm cultural values, which was an argument for continuing to grant loss of consortium awards to husbands and extending the right to wives. Denying both husbands and wives the claim might achieve equality, but it would not reflect cultural values.

84. Ibid., 8, 11.

85. Ibid., 16-17.

86. Ibid., 19. 
White offered the court an opportunity to strengthen marriage by adding to the benefits of marriage.

Glenn Beers and R. Bruce Hughes, the attorneys for the defendant, responded to White's argument with numerous references to cases denying wives the right to bring loss of consortium claims based on negligence. ${ }^{87}$ They noted that although no Iowa court had considered this particular issue, many courts had, and almost all had rejected White's argument. They repeated reasons for denying the claim found in other decisions and stated that "a mere listing of the cited cases [was] persuasive." 88

Without a central theme in their brief, oral argument did not go well for Beers and Hughes. White remembers that the defense lawyers argued unsuccessfully that granting the claim to wives would result in too many cases for the courts to handle. White also believes that Beers and Hughes made a crucial mistake at oral argument by noting that all the justices had represented insurance companies. White thinks the judges did not appreciate the insinuation that they did not decide cases independently. ${ }^{89}$

The Iowa Supreme Court found White's argument persuasive. The court reversed Judge Heath's dismissal of the case and held that wives do have a claim for loss of consortium based on negligence. Norman Hays, who wrote the opinion for the majority, squarely addressed the defense attorneys' reliance on previous case law.

While we recognize the almost total lack of precedent for allowing appellant's cause of action, we deem precedent to be worthy of support only when it can stand the scrutiny of logic and sound reasoning in the light of present-day standards and ideals. We think the reasoning and logic advanced in the Hitaffer case is sound; that the reasoning and logic advanced by the great weight of authority denying relief is not. ${ }^{90}$

The Iowa Supreme Court found that the married women's property acts had abolished coverture. The court also concluded that

87. Appellee's Brief and Argument, Acuff v. Schmit, 248 Iowa 272 (Iowa 1956) (No. 10-48939), 6-25.

88. Ibid., 6.

89. White interview.

90. Acuff, 248 Iowa at 280-81. 
consortium referred to love and affection rather than an economic exchange. White's focus on contrasting wives' rights in the modern era with wives' rights under coverture was a successful strategy; the court emphasized that contrast throughout its decision. ${ }^{91}$

Judge Hays found the contrast between current values and the values embedded in the concept of coverture especially striking. He described coverture as an "archaic rule" where "the husband and wife were considered as one, and he was the one." He declared that "a wife [was] no longer her husband's chattel." Using the terms "modern" and "today" several times in his opinion, Judge Hays indicated that the court's opinion was based in present values that differed dramatically from the values of coverture. Despite finding coverture "archaic," the court did not find the concept of loss of consortium, which had grown out of coverture, outdated. ${ }^{92}$ White had persuasively presented the case as an opportunity to strengthen marriage, and the court seized the opportunity to define the meaning of marriage for the "modern" era.

Four judges dissented. ${ }^{93}$ Henry Peterson, who wrote the dissenting opinion, emphasized that "the question involved in this case ha[d] been considered by the Supreme Court of at least twenty states" and only "two or three decisions" agreed with the majority while "more than fifty decisions" reached the opposite conclusion. He quoted at length from various decisions denying the wife the claim. ${ }^{94}$

Attorneys Beers and Hughes filed a petition for rehearing. They argued that "the decision of the majority would make Iowa an 'island' in the sea of judicial opinion." The defense lawyers again argued that the legislature should decide the issue because it involved "very grave policy questions." In his response, White cited Judge Benjamin Cardozo for the proposi-

\footnotetext{
91. Ibid., 274, 278-81.
}

92. Ibid., 274, 277-80. By contrast, the Iowa Supreme Court did abolish the alienation of affections action in Iowa in 1981, finding that the "theory [of recovery] was rooted in ideas [the court had] long since renounced, involving wives as property." Fundermann v. Mickelson, 304 N.W.2d 790, 791 (Iowa 1981).

94. Ibid., 281, 288-90. 
tion that changing the law when social customs changed was a judicial function. Agreeing with White, the court denied the petition for rehearing. ${ }^{95}$

Acuff v. Schmit was one of several cases in the mid-1950s in which the Iowa Supreme Court reversed precedent or decided a case differently from the majority of courts. This may have caused some consternation, for not long after the Acuff ruling, Judge Larson, who had sided with the majority in Acuff, prepared a speech describing the court's position with regard to stare decisis.

The volume of overruled precedents has led to the query as to whether or not we are without hesitation in upsetting established rules to reach justice in the case at bar. I do not so consider the make-up of our court. While there are perhaps a liberal or two, and a conservative or two, on this court, I could not classify the group as either liberal or conservative in its far-reaching policies or objectives. District judges and lawyers have no hesitancy in contending for positions they believe are correct, and we do carefully consider their arguments. ${ }^{96}$

Larson discussed nine cases, including Acuff, filed between December 1955 and October 1956 in which the court's decision was a reversal of precedent or a decision in conflict with other courts. The court, he claimed, was not interested in challenging current social mores, but it was committed to protecting the rights of every citizen. ${ }^{97}$

The Acuff decision reversed and remanded a ruling dismissing the case. Having established that a wife could claim loss of consortium, the Iowa Supreme Court directed District Court Judge Heath to hear the case. The case was set for trial in October 1957. Before the trial date, the insurance company offered to settle the case and Maude Acuff accepted. ${ }^{98}$ White recalled that

95. Appellee's Petition for Rehearing, Acuff v. Schmit, 248 Iowa 272 (Iowa 1956) (No. 10-48939), 2, 5; Appellant's Resistance to Petition for Rehearing, Acuff $v$. Schmit, 248 Iowa 272 (Iowa 1956) (No. 10-48939), 5.

96. Robert L. Larson, untitled speech ("It has been said, with some evidence of truth, that the Iowa Supreme Court is not unalterably bound to the rule of stare decisis"), folder: Speeches 1952, box 1: Speeches 1947-1952, Larson Collection. 97. Ibid.

98. Acuffs interview; White interview. 


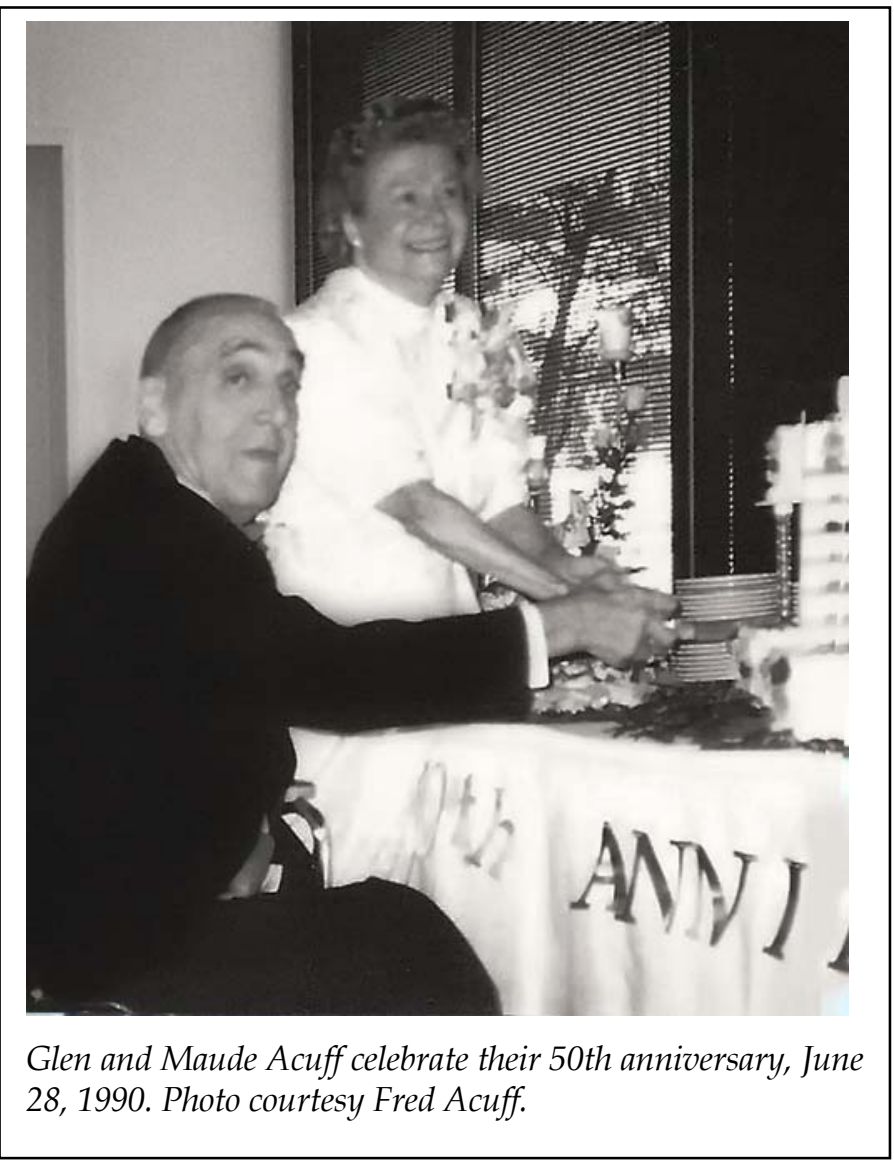

Maude did not want to go through the stress of a trial and felt "vindicated" by the Iowa Supreme Court's decision. In December 1957 White filed a motion to dismiss. ${ }^{99}$

IN THE NEARLY FOUR-AND-A-HALF YEARS between Glen Acuff's accident and the final resolution of Maude's loss of consortium suit, Maude and Glen began rebuilding their family life. Maude became a "working woman," advancing at Santa Claus Industries to the position of director of purchasing, a post she would hold until the company sold out in the mid-1960s.

99. Court documents, Acuff v. Schmit, 248 Iowa 272 (Iowa 1956) (No. 10-48939). 
Then, with the full responsibility of financial support for the family on her shoulders, Maude answered an ad for a medical records transcriber at St. Francis Hospital. At the hospital she worked her way up to the position of director of central services, a title she proudly held until she retired in 1992. ${ }^{100}$

At home, Glen was not idle. His sons became his arms and legs. With Glen providing supervision and direction, the boys remodeled the bathroom, cultivated and tended a truck garden, and canned vegetables. When the older boys moved on to other activities and left home, it fell to the youngest son, Fred, to replace them. He recalls boosting Glen onto the tractor to till the strawberries, following his father's direction to set up a mobile home, and, when he was 14, getting both of his parents in the car when his mother suffered a minor heart attack and, under his father's direction, driving to the hospital in Waterloo. ${ }^{101}$

Eventually Glen began assisting neighbors with their taxes, an endeavor he gradually expanded into a part-time seasonal business. Although he was proud of Maude's success at the jobs she held, the inability to support his family always ate at Glen. His son Fred put it this way: "One of the things my Dad's generation was adamant about was that a man supports the family. ... If there was one tough thing for my father when he broke his neck it was the idea that he couldn't support his family the way he envisioned that he should." Glen Acuff was 75 when he died on April 27, 1996. Maude died on August 20, 2010. ${ }^{102}$

Acuff $v$. Schmit established Frederick White's reputation as an attorney who was willing, once he took a case, to follow through to appeal if appropriate. Following the Acuff decision, Yale Law School placed the case in its moot court program, and White received inquiries from plaintiff and defense lawyers seeking to understand how he had developed his argument. ${ }^{103}$ White was well on his way to becoming a respected member of the Iowa Bar and establishing a general practice that extended across 50 years.

100. Acuffs interview.

101. Ibid.

102. Ibid.; "Metro Deaths-Glen Robert Acuff," Waterloo Cedar Falls Courier, 4/29/1996; "Obituaries - Maude L. Acuff 1922-2010.”

103. White interview. 
AFTER THE IOWA SUPREME COURT decided Acuff in 1956, courts around the country gradually allowed wives to bring loss of consortium claims based on negligence. ${ }^{104}$ Progress was uneven and slow; in the 1960s, 1970s, and 1980s, most states decided that the wife could recover, but some courts continued to issue decisions denying wives the claim, and as late as 1997 six states still denied recovery for the wife while granting it to the husband. ${ }^{105}$ Today all jurisdictions in the United States allow both husbands and wives to recover for loss of consortium based in negligence. In contrast, in England, where the loss of consortium claim and the doctrine of coverture originated, "courts came to regard all actions for loss of consortium as misconceived." In the United States, the debate between judges who would allow the claim and those who would deny it was at times lively, and the reasons judges gave for their positions illustrate the nuances in views on marriage and women in the mid-twentieth century. 106

The forceful dissenting opinions in two cases denying recovery show how a wife's right to the loss of consortium claim could be alternately framed as an equality issue or as a decision on the significance of marriage and its definition. In Deshotel $v$. Atchison, decided in 1958, the Supreme Court of California refused to allow the wife to recover for loss of consortium. Judge Jesse Carter, who wrote "frequent and outspoken" dissents, declared the majority's opinion "neither logical nor sound"; he could see no difference between a husband's loss of consortium and a wife's loss of consortium. He argued that the court's decision was "a denial of the equal protection of the laws guaranteed by both the federal and State constitutions." He believed that marriage gave the parties rights that, when destroyed, deserved compensation. Carter described the wife's loss in dramatic terms:

104. Minzer et al., eds., Damages in Tort Actions, 11.02[2][b].

105. Ibid.; Dorothy Stetson, Women's Rights in the USA: Policy Debates and Gender Roles (New York, 1997), 190-91; Neuberg v. Bobowicz, 162 A.2d 662 (Pa. 1960), overruled by Hopkins v. Blanco, 320 A.2d 139 (Pa. 1974); Deshotel v. Atchison, Topeka E Santa Fe Ry. Co., 328 P.2d 449 (Cal. 1958).

106. Richard A. Epstein, Cases and Materials on Torts (New York, 2004), 821; Neuberg v. Bobowicz, 162 A.2d 662 (Pa. 1960), overruled by Hopkins v. Blanco, 320 A.2d 139 (Pa. 1974). 
"In place of a healthy, normal husband she now has a hopelessly bedridden invalid." His reasoning reflected sentiments expressed in other cases, but, unlike the judges in many of those other cases, he explicitly named the denial of the claim a denial of equal protection. He saw the case through the lens of gender equality. 107

In Neuberg v. Bobowicz, decided in 1960, the Supreme Court of Pennsylvania also refused to allow the wife to recover for loss of consortium, finding that the action was, "at best, a vague, indefinable and embarrassing left-over from another day and age." Judge Michael Musmanno, also well known for his dissenting opinions, wrote a lengthy dissent in which he expressed outrage at the majority's opinion, which he believed "reduce[d] the holy relationship of married life to one of a mere business partnership." Judge Musmanno saw Neuberg as a case about whether to strengthen or weaken "the most respected relationship in civilization, the marriage relationship." Judge Musmanno celebrated gender roles within marriage and believed the married women's property acts strengthened that structure.

The remedial legislation [married women's property acts] was not aimed at toppling over the husband. The husband is still the head of the household, he is still the person responsible for the security of the home, he is still the protector of his wife and children, all of which, of course, he should be. ... The remedial legislation ... has increased rather than diminished the strength of the bonds of mutuality between her and husband. If it did not do that, it could scarcely be regarded as 'remedial.' Anything which weakens the marital status is catastrophic, not remedial.

Denying the wife recovery for loss of consortium was denying the sanctity of marriage and its significance in society. ${ }^{108}$

Judge Musmanno contrasted his definition of marriage with the majority's definition, concluding that gender was irrelevant

107. Deshotel v. Atchison, Topeka \& Santa Fe Ry. Co., 328 P.2d 449, 451-52, 454, 455 (Cal. 1958); Corinne Lathrop Gilb, "Justice Jesse W. Carter, An American Individualist," Pacific Historical Review 29 (1960), 145; Rodriguez v. Bethlehem Steel Corp., 525 P.2d 669 (Cal. 1974), later overruled Deshotel. See Boeken v. Philip Morris USA, Inc., 230 F.3d 342, 347 (Cal. 2010).

108. Neuberg v. Bobowicz, 162 A.2d 662, 666, 675-77 (Pa. 1960); Joel Fishman, "Justice Michael A. Musmanno and Constitutional Dissents, 1967-68," Albany Law Review 68 (2004-2005), 350. 
in the majority's definition. He lamented that "it used to be that when Mary Quadrille married John Cabot they truly became Mr. and Mrs. Cabot. Under today's decision, the wedded couple will become Quadrille \& Cabot, Partnership." 109 In his formulation, gender matters; the couple would use "Mr." and "Mrs." in Musmanno's ideal marriage. The couple would also share the same name. Under the majority's definition of marriage, gender is irrelevant and the couple retains their separate names. Musmanno argued that denying the wife recovery actually destroyed gender roles, while allowing recovery would strengthen them.

Judge Musmanno also emphasized the distinctive nature of the wife's loss. Believing that the family was "the flesh and blood of our American civilization," Musmanno asked how depriving the "sacred right to motherhood" could "mean nothing to the law." He believed that a woman was entitled to "comfort, companionship, society and love" when she "[gave] up her home and family" to join her husband. ${ }^{110}$ Her loss of consortium was a gendered loss. The different approaches of Judges Carter and Musmanno reflected conflicting cultural responses to the changing nature of marriage and gender roles.

Indeed, in the 1950s, when many families were separated from extended family and other social ties and wives often stayed at home, the loss of a husband's companionship would have been a significant loss. The expansion of suburbs "weakened extended-family ties . . . and fostered a style of life based on traditional gender roles in the home." 111 Weakened ties between extended family members elevated the significance of marriage in people's lives. The Iowa Supreme Court and other courts decided loss of consortium cases in the context of a culture where the importance of marriage was growing.

An inability to have children was also particularly significant to women at that time. As Elaine Tyler May explains, "The message in the popular culture was clear: Motherhood was the ultimate fulfillment of female sexuality and the primary source of a woman's identity." 112 According to Judge Musmanno, al-

109. Neuberg, 162 A.2d at 674.

110. Ibid., 668-69.

111. May, Homeward Bound, 166.

112. Ibid., 135. 
lowing the wife to recover for loss of consortium recognized and celebrated the traditional gender structure the wife had lost in her marriage through the injury to her husband.

Arguments based in the concept of equality could have led to widespread abolition of the loss of consortium action altogether, but the cultural background of the 1950s provided judges with persuasive reasons to allow wives to recover. Later cases more clearly addressed the concept of equality, but judges decided those cases in the context of the earlier cases. ${ }^{113}$ Acuff and other early cases established authority that later judges could rely upon.

THE LEGAL RIGHTS of wives have been extended in the years since Acuff, but economic equality between men and women remains elusive. Because women remain largely responsible for household labor and care of dependents and because the "ideal employee" is often expected to be available for full-time and overtime work, women often remain dependent on men. ${ }^{114}$ The effects of coverture in shaping marital roles persist.

The judges who allowed wives to recover for loss of consortium recognized a wife's disadvantage before the law, but they did not question the inequality inherent in the economic structure of the marital relationship. Despite the focus on love and affection in marriage in many decisions, the result of allowing a wife to bring a loss of consortium claim was a monetary award. That monetary award was an acknowledgment of the inequality of economic opportunity facing a wife who struggled to support the family after her husband could no longer provide that support. Because Maude Acuff's monetary award was small, she needed to get a job outside the home, which reversed gender roles in the marriage. However, a monetary award does contribute to a wife's ability to maintain the traditional eco-

113. Hopkins v. Blanco, 320 A.2d 139 (Pa. 1974).

114. For a discussion of the persistence of wives' subordination and dependency within the marital relationship even after the dismantling of coverture, see Martha Fineman, The Autonomy Myth: A Theory of Dependency (New York, 2004), 1-28, 110-200; Sullivan, Constitutional Context, 1-22, 41-150; Williams, Unbending Gender, 1-39, 115-20. 
nomic structure of the marital relationship. In this way, a monetary award may reinforce the wife's role as a dependent.

Allowing a wife to recover for loss of consortium allowed the state to "pass the costs of welfare on to private individuals." 115 If a wife received money from a private citizen for the consequences of a disruption in her marital relationship, her family would not be forced to rely heavily on the state for economic assistance. This recovery added to the benefits of marriage, an institution itself designed to ensure that the state does not have to pay these costs, according to Martha Fineman. Fineman argues that "the institution of the family frees the market to act without consideration or accommodation for dependency." As Joan Williams puts it, "Mothers marginalize to enable fathers to perform as ideal workers." This family structure perpetuates gender inequality by assigning care for dependents to women, who are then unable to perform as "ideal workers" in the economy in the way that men can. Allowing a wife to recover for loss of consortium made sense within a system designed to ensure that the state would not be responsible for dependents. ${ }^{116}$

Decisions allowing wives to bring loss of consortium claims did not radically restructure gender roles or question the institution of marriage. These decisions did, however, reflect a change in the cultural understanding of marriage in the midtwentieth century. Previously seen as an economic exchange, marriage now also signaled companionship and romantic and sexual love; it became one of the principal sources of emotional support in many people's lives.

The Iowa Supreme Court decided Acuff in the context of a culture that celebrated marriage as the primary relationship in people's lives. This cultural background made possible the gradual emergence of the wife's right to loss of consortium based on negligence. Courts could have rejected the claim for both wives and husbands by finding the claim rooted in outdated concepts. Instead, they found the claim relevant. Marriage and the common understanding of its significance in the culture were central themes in the decisions allowing wives to bring

115. Hartog, Man and Wife, 159.

116. Fineman, The Autonomy Myth, 37; Williams, Unbending Gender, 39, 115. 
loss of consortium claims. The cultural landscape of the 1950s, when marriage defined people's lives, allowed for the continuation and expansion of the loss of consortium claim. 